\title{
LEAF ANATOMY AND GAS EXCHANGE OF ORNAMENTAL SUNFLOWER IN RESPONSE TO SILICON APPLICATION
}

\author{
ANATOMIA FOLIAR E TROCAS GASOSAS DE GIRASSOL ORNAMENTAL EM \\ FUNÇÃO DA APLICAÇÃO DE SILÍCIO NO SUBSTRATO
}

\author{
Luiz Antônio ZANÃO JÚNIOR'; ${ }^{1}$ Victor Hugo ALVAREZ VENEGAS ${ }^{2}$; \\ Renildes Lúcio Ferreira FONTES²; Maristela Pereira CARVALHO-ZANÃO ${ }^{1}$; Jaqueline DIAS- \\ PEREIRA $^{3}$; Leila Teresinha MARANHO ${ }^{4}$; Natália PEREIRA ${ }^{5}$ \\ 1. Instituto Agronômico do Paraná - IAPAR, Santa Tereza do Oeste, PR, Brasil; 2. Universidade Federal de Viçosa - UFV, Viçosa, MG, \\ Brasil; 3. Universidade Federal de Viçosa, Campus Rio Paranaíba - UFV/CRP, Rio Paranaíba, PR, Brasil; 4. Universidade Positivo - \\ UP, Curitiba, PR, Brasil; 5. Universidade Estadual do Oeste do Paraná - UNIOESTE, Cascavel, PR, Brasil. lzanao@iapar.br
}

\begin{abstract}
Silicon applied to substrate for greenhouse cultivation of ornamental pot plants can improve the yield and quality of the ornamental product; however, the possible anatomical and physiological changes caused by $\mathrm{Si}$ have to be assessed. Therefore, the objective of this study was to evaluate gas exchange rates and leaf anatomy of ornamental sunflower 'Sunbright' grown on a substrate amended with Si. The experiment was conducted in a greenhouse, and the treatments consisted of sunflower plants cultivated in pots containing $600 \mathrm{~g}$ substrate fertilized with Si at rates of $0,0.25,0.50,0.75$, and $1.00 \mathrm{~g} \mathrm{~kg}^{-1}$. The treatments were arranged in randomized complete block design and four replications. Samples from the middle region of leaf blades in the sixth pair from the apex were collected and analyzed morphometrically. Epidermal trichomes were analyzed using diaphanization and scanning electron microscopy with energy-dispersive X-ray spectroscopy. The following traits were determined: leaf blade thickness, palisade and spongy parenchyma thickness, mesophyll thickness, and abaxial and adaxial epidermis thickness. Net photosynthesis, stomatal conductance and transpiration rates were determined in the fifth leaf at the beginning of the flowering stage by an infrared gas analyzer. The data were subjected to ANOVA and regression analyses. The results indicate that the ornamental sunflower 'Sunbright' accumulates Si in leaf trichomes, and that leaf thickness is not affected by Si application to the substrate; however, transpiration rates decrease while net photosynthesis rate and stomatal conductance increase in response to $\mathrm{Si}$ application.
\end{abstract}

KEYWORDS: Helianthus annuus L. Photosynthesis. Micromorphometry.

\section{INTRODUCTION}

Silicon $(\mathrm{Si})$ is the second most abundant element in the earth's crust after oxygen (EPSTEIN, 1999). In certain grasses, more $\mathrm{Si}$ is absorbed than macronutrients and in others, more $\mathrm{Si}$ than phosphorus, magnesium and sulfur. Silicon is not considered essential since there is no evidence of its participation in any physiological process (CURRIE; PERRY, 2007). To date, very little information has been consolidated on the specific role of Si in plants; however, this element seems to be (directly or indirectly) involved in cellular metabolism, although its mode of action is still unclear, especially in plants under biotic and abiotic stress conditions (MA; YAMAJI, 2008; GUNTZER et al., 2012; TRIPATHI et al., 2014).

In plants, $\mathrm{Si}$ is absorbed in the form of monosilicic acid $\left(\mathrm{H}_{4} \mathrm{SiO}_{4}\right)$, which is immediately translocated to the leaves. There, as water is lost through transpiration, $\mathrm{H}_{4} \mathrm{SiO}_{4}$ is gradually concentrated and polymerized, first in colloidal form and finally in the form of silica gel, or amorphous or biogenic silica $\left(\mathrm{SiO}_{2} \cdot n \mathrm{H}_{2} \mathrm{O}\right)$, and immobilized (MA et al., 2001; IMTIAZ et al., 2016). Therefore, more mature tissues contain larger amounts of silica (MA; YAMAJI, 2008). Si can be deposited either intra- or extracellularly, mainly in epidermal cells. Silica deposited intracellularly can fill up almost the entire cell, and extracellularly is placed under the cuticle. The association with the cuticle layer of silica is usually called the cuticlesilica double layer (EPSTEIN, 1999).

Silicon is beneficial for crops in several ways, for example it minimizes biotic and abiotic stress conditions (pests and diseases, toxicity caused by excessive metals, salinity, low temperatures, and drought) (MA, 2015). Most benefits provided by Si to plants are caused by intracellular deposits of amorphous silica and the cuticle-silica double layer, which increase the rigidity and resistance of plant tissues (MA; YAMAJI, 2008; SIVANESAN; PARK, 2014). In grasses such as rice, aside from extracellular deposits, $\mathrm{Si}$ is deposited internally in siliceous cells (also known as silica bodies), in bulliform cells, and in vascular stomata bundles 
(CURRIE; PERRY, 2007). The location of deposition, however, appears to depend on the species or botanical family. Frantz et al. (2008) evaluated 14 ornamental species and found that the location of silica accumulation is species-specific, but occurs mostly in the leaf trichomes and on the margins of the leaf blade.

Higher resistance to water stress observed in silicon-treated sunflower (GUNES et al., 2008), sorghum (YIN et al., 2014) and rice (LAVINSKY et al., 2016) may be due to anatomical changes induced by $\mathrm{Si}$, which consequently lead to lower transpiration and higher photosynthetic rates. These effects render plants that are more efficient in water use. In the case of rice, the higher water stress resistance can be explained by the double silica layer in the leaves, causing reduction of transpiration by reducing stomatal opening and cuticular transpiration, thus restricting water loss and reducing water requirement of the plant (MA; YAMAJI, 2008).

The use of $\mathrm{Si}$ in the cultivation of some ornamental pot plants can improve the yield and quality of the final product, but possible physiological and anatomical changes caused by this element need evaluation. Therefore, the purpose of this study was to assess leaf anatomy and gas exchange of ornamental sunflower 'Sunbright' in response to the application of Si to the substrate.

\section{MATERIAL AND METHODS}

The experiment was conducted from October to December 2008 in a greenhouse that belongs to the Federal University of Viçosa. The average daily minimum and maximum temperatures were 17.3 and $33.9^{\circ} \mathrm{C}$, respectively, and the diurnal and nocturnal average air humidity was 65.6 and $85.5 \%$, respectively.

Five rates of $\mathrm{Si}(0,0.25,0.50,0.75$, and 1.00 $\mathrm{g} \mathrm{kg}^{-1}$ ) were applied to the substrate in plastic pots using potassium metasilicate $\left(\mathrm{K}_{2} \mathrm{SiO}_{3}\right)$ solution. The experiment was carried out with treatments arranged in randomized complete blocks with four replications. One experimental unit consisted of one sunflower plant in a pot $\left(10 \mathrm{~cm}\right.$ high, $800 \mathrm{~cm}^{3}$ in volume) containing $600 \mathrm{~g}$ of the substrate Plantmax ${ }^{\circledR}$. Sunflower seedlings were grown from seeds of the cultivar 'Sunbright' (Sakata Seed Sudamérica Ltda.). Six days after seed emergence, when the seedlings were about $8 \mathrm{~cm}$ high and had one fully expanded leaf, the plants were transplanted to the pots.

The plants were irrigated daily, and fed every other watering with a nutrient solution recommended for ornamental flowers. The following are the nutrients supplied in the nutrient solution (ZANÃO JÚNIOR et al., 2013) during the experiment and their doses $\left(\mathrm{mg} \mathrm{kg} \mathrm{kg}^{-1}\right.$ of the substrate): $200 \mathrm{~N}, 350 \mathrm{P}, 150 \mathrm{Ca}, 100 \mathrm{Mg}, 80 \mathrm{~S}, 1.2$ $\mathrm{B}, 0.5 \mathrm{Cu}, 2 \mathrm{Fe}, 1.5 \mathrm{Mn}, 0.1 \mathrm{Mo}$, and $1 \mathrm{Zn}$.

Each Si rate was split into five applications ( $20 \%$ of the total Si rate). The first application was made fifteen days after transplanting, and the other four applications were carried out the following weeks. Since $\mathrm{K}_{2} \mathrm{SiO}_{3}\left(120 \mathrm{~g} \mathrm{~kg}^{-1} \mathrm{Si}\right.$ and $150 \mathrm{~g} \mathrm{~kg}^{-1}$ $\mathrm{K}_{2} \mathrm{O}$ ) forms an alkaline solution $(\mathrm{pH}>10)$, $\mathrm{pH}$ was lowered to 6.0 with $2 \mathrm{~mol} \mathrm{~L}^{-1} \mathrm{HCl}$. In treatments without $\mathrm{Si}$ applications, or with low $\mathrm{Si}$ doses $\left(\mathrm{K}_{2} \mathrm{SiO}_{3}\right), \mathrm{K}$ was supplied as $\mathrm{KCl}$ to establish a nutrient balance among the treatments.

The growth retardant paclobutrazol (PBZ) a plant growth hormone inhibitor-was applied weekly directly to the substrate at a dose of $1 \mathrm{mg}$ per week during seven weeks. When more than $50 \%$ of the capitulum flowers were open, plant gas exchange rates were measured and leaf samples for anatomical studies were collected. The side shoots were eliminated at this phase.

To determine net photosynthesis, transpiration, and conductance rates, gas exchange rates in the fifth pair of leaves from the apex were measured using a portable infrared gas analyzer (IRGA), model LC $\mathrm{Pro}^{+}$(Analytical Development Company, Hoddesdon, UK) attached to a Parkinson leaf chamber with air flow rate of $200 \mathrm{~cm}^{3} \mathrm{~min}^{-1}$. The IRGA was coupled to an artificial light source to provide photon irradiance of $1044 \mu \mathrm{mol} \mathrm{m}^{-2} \mathrm{~s}^{-1}$ on the leaf blade surface. Five measurements per experimental unit were carried out on sunny days.

To study the leaf anatomy, samples of 9.0 $\mathrm{cm}^{2}$ were collected from the intermediate region of the blade of the sixth leaf from the apex in each plant. Next, the samples were fixed in $\mathrm{FAA}_{50}$ for 48 $\mathrm{h}$, soaked in ethanol $70 \mathrm{cL} \mathrm{L}^{-1}$ (JOHANSEN, 1940), and embedded in glycol methacrylate (Hardener Leica Historesin, Leica Mycrosistems Nußloch $\mathrm{GmbH}$, Germany), according to the manufacturer's recommendations. Thin sections $(5 \mu \mathrm{m})$ were transversely cut from the block in an automated microtome. The sections were stained for $5 \mathrm{~min}$ with toluidine blue $\mathrm{pH} 4.0$ (O'BRIEN et al., 1964), for metachromatic staining of the tissues. The slides were mounted on coverslips with synthetic resin (Permount - SP15-500, Fisher Scientific, New Jersey, USA). The diaphanization method was used to analyze leaf trichomes (FOSTER, 1949).

The slides were observed under a microscope light (AX70 TRF, Olympus Optical) with U-PHOTO system coupled to a Spot Insight 
digital camera (model 3.2.0, Diagnostic Instruments Inc) and a microcomputer with the image capture software Spot Basic, at the Plant Anatomy Laboratory, Department of Plant Biology, Federal University of Viçosa.

Micromorphometric data were obtained by analyzing scanned images with Image-Pro Plus 4.5 software. The following variables were evaluated: leaf thickness, mesophyll, palisade and spongy parenchyma, and the adaxial and abaxial leaf epidermis.

For scanning electron microscopy (SEM), samples of leaves were fixed in $\mathrm{FAA}_{50}$ and dehydrated in increasing ethanol series. Drying to the critical point was performed with liquid $\mathrm{CO}_{2}$ in an automated critical point dryer model CPD 020 (Bal-Tec, Balzers, Liechtenstein). After gold sputter coating model FDU010 (Bal-Tec, Balzers, Liechtenstein), the adaxial and abaxial leaf surfaces were evaluated using scanning electron microscope coupled to a digital camera at the Center for Microscopy and Microanalysis, UFV.

Samples for energy-dispersive spectroscopy (EDS) analysis, which was carried out in the Laboratory for Microscopy and Microanalysis, State University of Londrina, were taken and prepared from the same leaves used for SEM. Ten fragments were cut and mounted on aluminum supports-half with the adaxial surface upwards and the other half with the abaxial surface upwards. Next, the specimens were dried for $24 \mathrm{~h}$ in a desiccator containing silica gel and, subsequently, sputtered (MED 010 Balzer) with a thin layer of $\mathrm{C}$ for analysis by SEM-EDS model FEI Quanta 200 ESEM at $25 \mathrm{kV}$ and a working distance of $12 \mathrm{~mm}$.

The data were subjected to ANOVA analyses, and regression equations were adjusted for the evaluated variables as a function of the Si doses applied with the coefficients tested by the $F$-test. Linear, square root, quadratic and cubic models were tested for the studied variables. The models were chosen based on the significance of regression coefficients, biological significance and the coefficient of determination.

\section{RESULTS AND DISCUSSION}

The anatomy of sunflower leaves is typical of the Asteraceae family, as described by Metcalfe and Chalk (1957). The mesophyll is dorsiventral: the adaxial side is composed of 2-3 layers of palisade parenchyma containing most of the chloroplasts, and the abaxial side is composed of 57 layers of spongy parenchyma. The vascular bundles are collateral and irregularly dispersed due to reticulate venation. The bundles in the center are larger and more mature. The medium-sized vascular bundles have sclerenchyma caps (Figure 1A).

The epidermis consists of a single layer of cells, with thin walls of polygonal contour on the adaxial and sinuous on the abaxial side. The leaf is amphistomatic, but the number of stomata on the adaxial surface is higher (Figure 1A). The stomatic complex is anomocytic.

The leaves have numerous trichomes on either side. The three main types are simple glandular trichomes: short uni- or multicellular, long multicellular, and spiral multicellular (Figure 1B). The density of long multicellular trichomes is higher along the veins, particularly on the abaxial surface and on the leaf edges, which is visible to the naked eye (Figure 1C).

The Si rates applied to the substrate did not significantly change the thickness of the sunflower epidermis, parenchyma, mesophyll or leaf blades (Table 1).

Cunha and Nascimento (2008) found that $\mathrm{Si}$ increased the thickness of the adaxial epidermis of corn leaves. In that case, the epidermis was possibly thickened by the deposition of $\mathrm{Si}$ in the form of hydrated amorphous silica $\left(\mathrm{SiO}_{2} \cdot n \mathrm{H}_{2} \mathrm{O}\right)$ in epidermal cells. According to Gong et al. (2005), this silica is deposited extracellularly, particularly in cells under the cuticle. In grasses, silica deposition in epidermal cells forms a mechanical barrier called cuticle-silica double layer, which reduces transpiration (thus improving the plant efficiency of water use), and increases the resistance of plants to pathogens (AGARIE et al., 1998; ASHRAF et al., 2010).

Soares (2012) found no effect of Si on the epidermis thickness of gerbera leaves, which like sunflower also belongs to the Asteraceae family. In the case of sunflower, what can possibly explain this fact is the accumulation of $\mathrm{Si}$ in higher amounts in the trichomes. If $\mathrm{Si}$ was primarily accumulated in the trichomes, the accumulation beneath the epidermis would be insufficient to induce a significant increase in epidermal thickness. Therefore, the accumulation of $\mathrm{Si}$ in the leaf trichomes may be a pattern in the dicotyledonous species. 

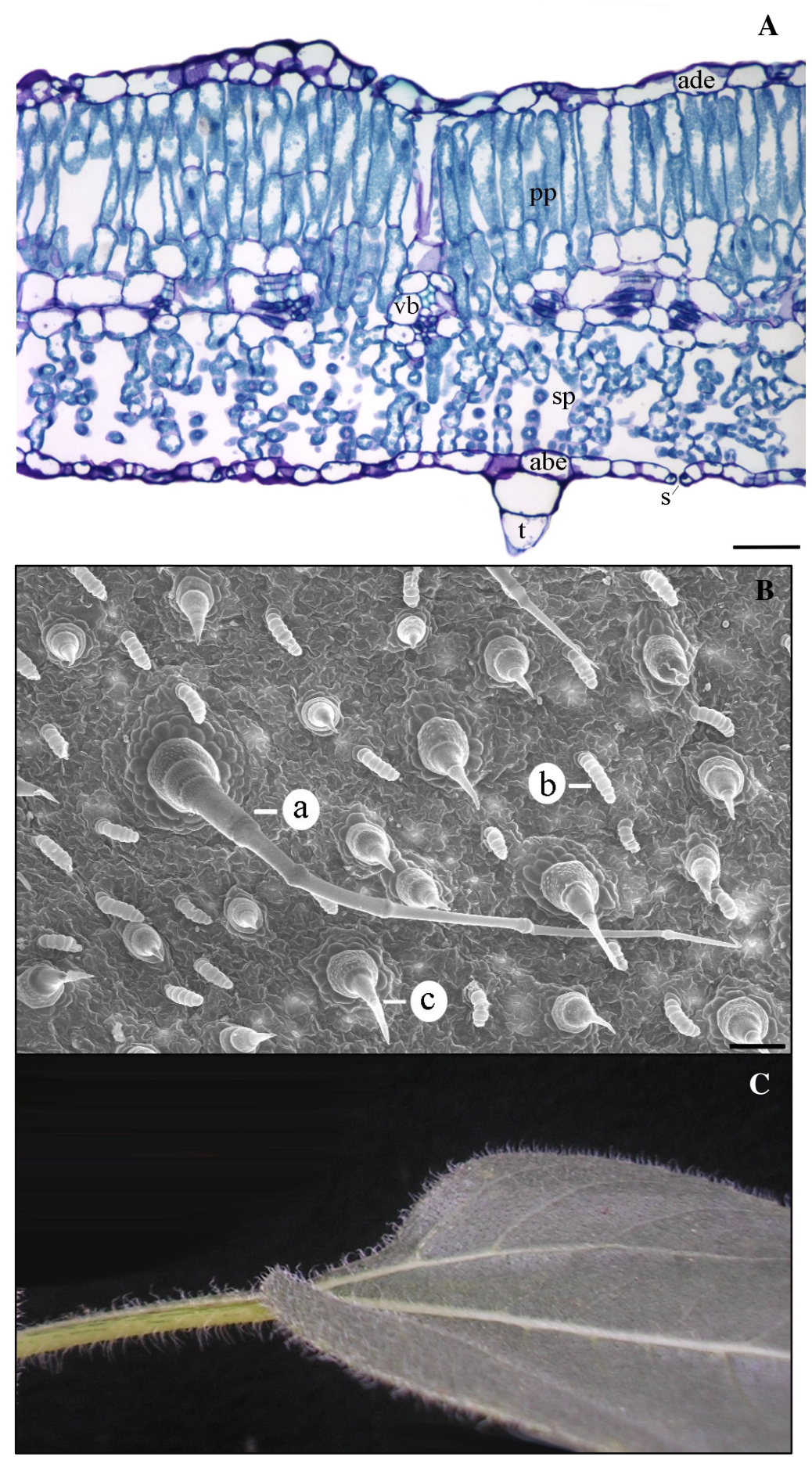

Figure 1. (A) Cross section of the leaf of ornamental sunflower 'Sunbright': ade $=$ adaxial epidermis, abe = abaxial epidermis, $\mathrm{s}=$ stomata, $\mathrm{vb}=$ vascular bundle, $\mathrm{sp}=$ spongy parenchyma, $\mathrm{pp}=$ palisade parenchyma and $t=$ trichomes. Scale bar $=50 \mu \mathrm{m}$. (B) Scanning electron micrograph of the adaxial surface of a sunflower leaf showing different types of trichomes: $a=$ simple multicellular long tector, $\mathrm{b}=$ simple multicellular spiraled tector, and $\mathrm{c}=$ simple multicellular short tector. Scale $\mathrm{bar}=$ $100 \mu \mathrm{m}$. (C) Sunflower leaf showing simple multicellular long tector trichomes along the petiole, veins and margins of the leaf blade. 
Table 1. Thickness of the epidermis, parenchyma, mesophyll and leaf blade of sunflower plants grown on substrate treated with different Si rates.

\begin{tabular}{|c|c|c|c|c|c|c|}
\hline \multirow[t]{2}{*}{ Si rate } & \multicolumn{6}{|c|}{ Thickness } \\
\hline & LF & ADE & MES & PP & SP & $\mathrm{ABE}$ \\
\hline $\mathrm{g} \mathrm{kg}^{-1}$ & \multicolumn{6}{|c|}{---------------------------------------------- $\mu \mathrm{m}$----------------------------------------------- } \\
\hline 0 & 704 & 45 & 623 & 387 & 236 & 36 \\
\hline 0.25 & 738 & 50 & 650 & 414 & 236 & 38 \\
\hline 0.50 & 613 & 35 & 549 & 358 & 191 & 29 \\
\hline 0.75 & 643 & 35 & 578 & 361 & 217 & 30 \\
\hline 1.00 & 521 & 31 & 464 & 301 & 163 & 26 \\
\hline$\hat{\mathrm{y}}=\overline{\mathrm{y}}$ & 644 & 40 & 573 & 364 & 209 & 32 \\
\hline CV \% & 22.07 & 21.06 & 23.22 & 18.72 & 31.58 & 16.16 \\
\hline
\end{tabular}

$\mathrm{LF}=$ leaf blade, $\mathrm{ADE}=$ adaxial epidermis, $\mathrm{MES}=$ mesophyll, $\mathrm{PP}=$ palisade parenchyma, $\mathrm{SP}=$ spongy parenchyma, and $\mathrm{ABE}:$ abaxial epidermis.

For the sunflower grown on Si-treated substrate $\left(1 \mathrm{~g} \mathrm{~kg}^{-1} \mathrm{Si}\right)$, the energy dispersive spectroscopy (EDS) detected Si accumulation in all three trichome types on either side of the leaf blade, particularly in the short trichomes classified as multicellular, followed by coiled multicellular, and to a lesser extent in the long multicellular trichomes. Aside from the trichomes, the other cells of the epidermis also accumulated $\mathrm{Si}$ on both sides, but to a lesser extent. In plants without $\mathrm{Si}$ application to the substrate, no $\mathrm{Si}$ accumulation was detected by EDS in any of the trichomes or in other epidermal cells (Figure 2). Lanning and Eleuterius (1989) found $\mathrm{Si}$ accumulated in leaf trichomes of three species of the genus Helianthus, particularly in the species Helianthus tuberosus.

Frantz et al. (2008) stated that the location of $\mathrm{Si}$ accumulation varies according to the ornamental species, with the highest accumulation rates in the trichomes and in the margins of the leaf blade. Hajiboland et al. (2008) observed high Mn accumulation in sunflower leaves and high tolerance to the excesses of this micronutrient, and found this to be a function of the trichomes as well. The same authors found that at high $\mathrm{Mn}$ doses, the short multicellular trichomes showed symptoms of complete oxidation, while in the long multicellular trichomes signs of rust were only observed in the basal or apical cells; no symptoms were observed in the coiled trichomes.

The symptoms consisted of cell darkening resulted from $\mathrm{Mn}$ oxide accumulation. These authors concluded that sunflower leaf trichomes have the function of accumulating chemical elements that can boost plant's tolerance to environmental stress conditions. The trichome color, obtained in the process of diaphanization of the sunflower leaves, allowed to calculate the trichome density (Figure 3).
Reduced transpiration and higher net photosynthesis were observed with increasing $\mathrm{Si}$ rates applied to the substrate, fitting the quadratic model presented in Table 2. Ma and Yamaji (2015) also reported that $\mathrm{Si}$ reduced leaf transpiration in rice.

According to Eneji et al. (2008), wheat plants under drought stress conditions and treated with $\mathrm{Si}$ present higher stomatal conductance and relative water content than untreated plants. Furthermore, the plants develop thicker and larger leaves, consequently limiting the loss of water through transpiration.

In plants under salt and water stress conditions, $\mathrm{Si}$ application reduces negative stress effects by diminishing transpiration rate (ASHRAF et al., 2010; GAO et al, 2004; HATTORI et al., 2005). Hossain et al. (2002) claimed that the reduced transpiration rate in rice after $\mathrm{Si}$ application is mainly caused by reduced stomatal pore transpiration, as also mentioned by Hasanuzzaman et al. (2014). According to Savant et al. (1999), in sugarcane leaves with high Si contents, this element fills up the interfibrillar spaces, consequently reducing water movement through the cell wall, which in turn decreases transpiration and increases water savings in plants.

Transpiration occurs in two forms: through the stomata and through the cuticle (KERBAUY, 2004; IMTIAZ et al., 2016). In the case of sunflower, it is still unclear what mechanisms reduce transpiration and increase the photosynthesis and stomatal conductance rates, which requires further studies. 


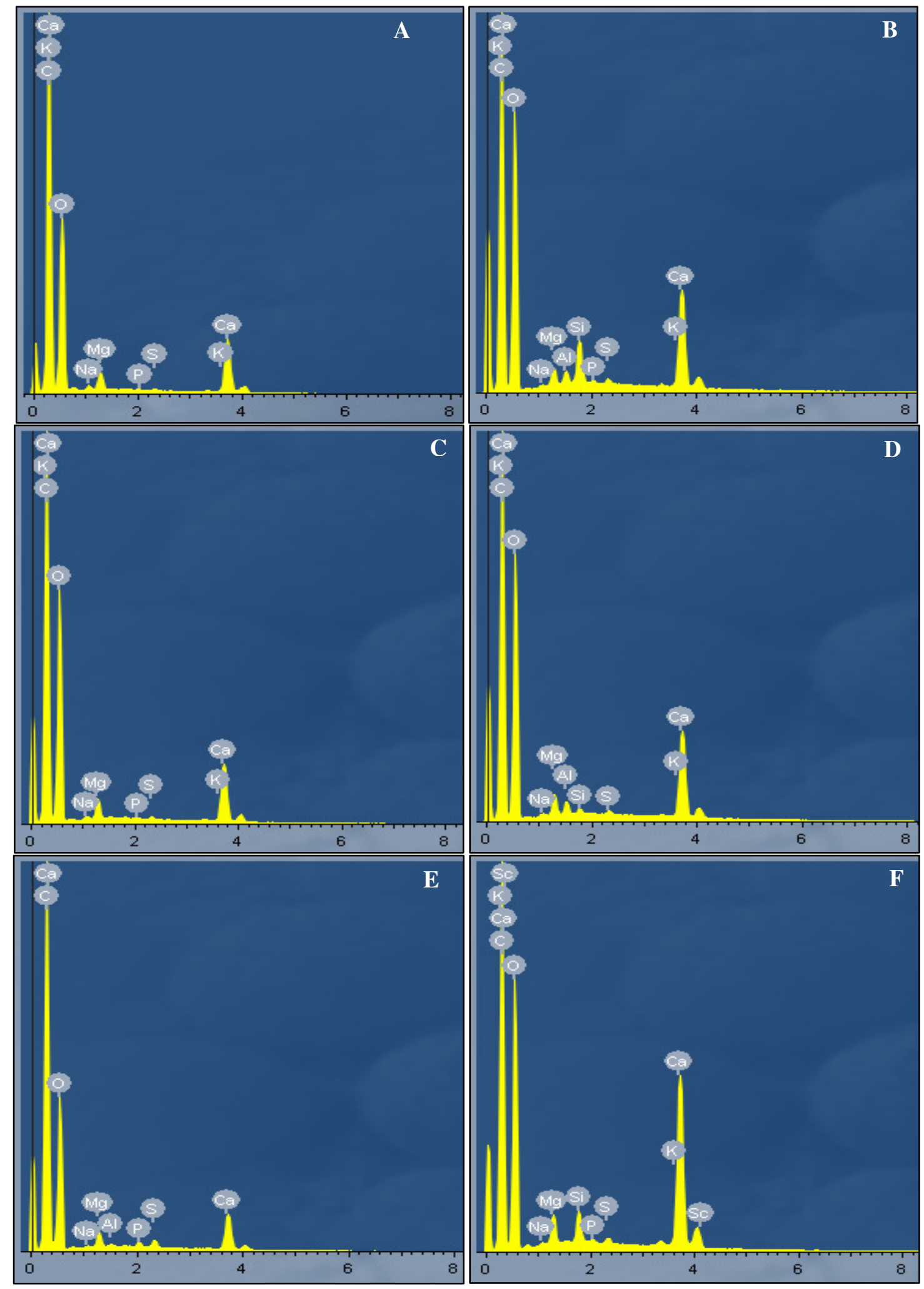

Figure 2. Energy-dispersive X-ray microanalysis (EDS) spectra of leaf trichomes of ornamental sunflower 'Sunbright': (A) and (B) simple multicellular short tector; (C) and (D) simple multicellular long tector; and (E) and (F) simple multicellular spiraled tector. (A), (C) and (E) plants grown on substrate without $\mathrm{Si}$; (B), (D) and (F) plants grown on substrate treated with $1 \mathrm{~g} \mathrm{~kg}^{-1} \mathrm{Si}$. Graph scale: Total vertical $60 \mathrm{cps}$; horizontal $=\mathrm{keV}$. 


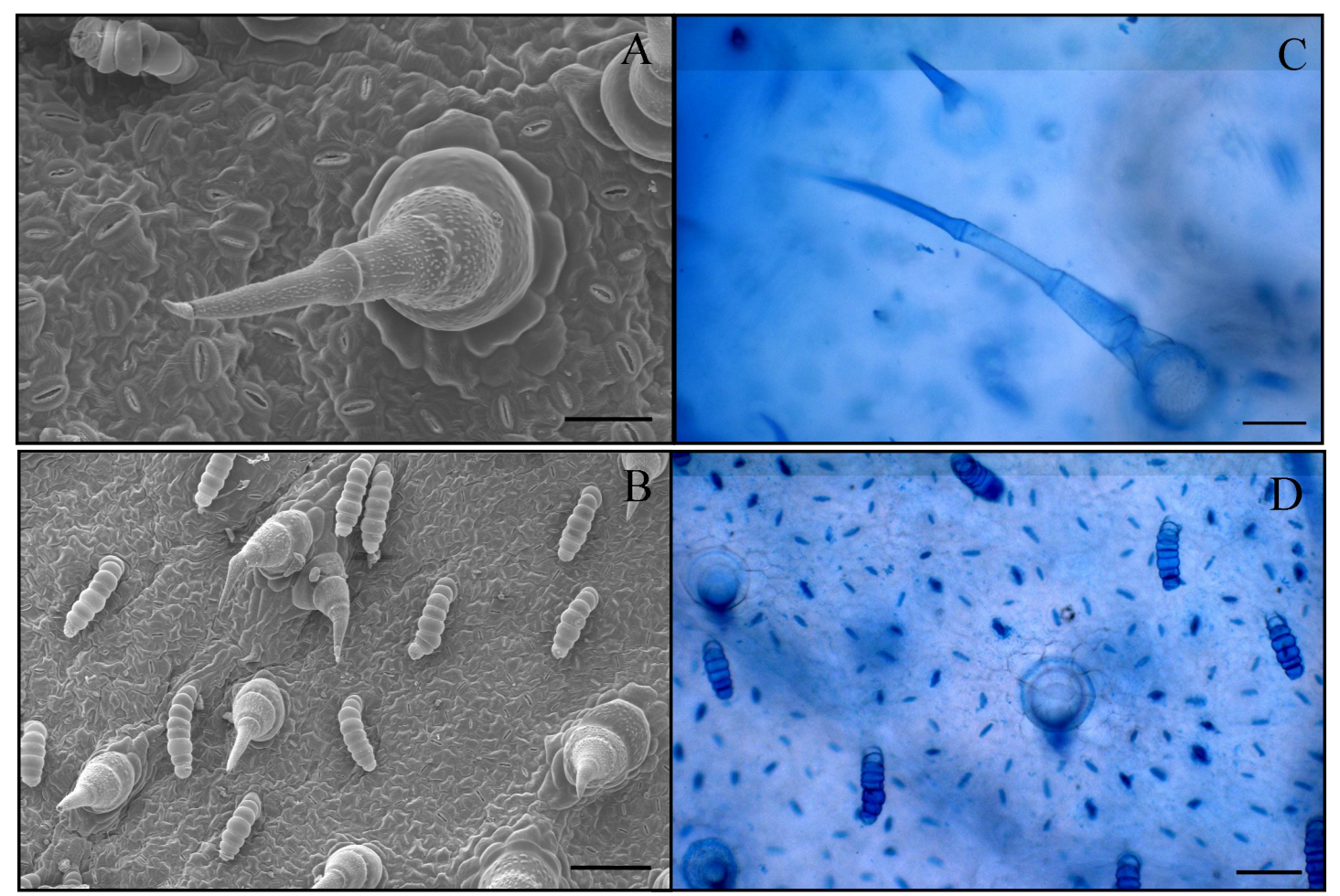

Figure 3. (A) and (B) scanning electron micrograph of the adaxial leaf surface with details of the different types of trichomes. (C) and (D) details of trichomes in diaphanous material. Scale bars: $(A)=20$ $\mu \mathrm{m},(\mathrm{B})$ and $(\mathrm{C})=100 \mu \mathrm{m},(\mathrm{D})=50 \mu \mathrm{m}$.

Table 2. Equations of net photosynthesis $(A)$, transpiration rate $(E)$ and stomatal conductance $\left(g_{\mathrm{s}}\right)$ of leaves of ornamental sunflower in relation to Si rates $\left(\mathrm{g} \mathrm{kg}^{-1}\right)$ applied to the substrate.

\begin{tabular}{ccc}
\hline Variable & Equation & $\mathrm{R}^{2}$ \\
\hline$A, \mu \mathrm{mol} \mathrm{m}{ }^{-2} \mathrm{~s}^{-1}$ & $\hat{\mathrm{y}}=28.076+13.611 \mathrm{x}-9.625^{*} \mathrm{x}^{2}$ & 0.954 \\
$E, \mathrm{mmol} \mathrm{m}^{-2} \mathrm{~s}^{-1}$ & $\hat{\mathrm{y}}=8.646+0.192 \mathrm{x}-1.031^{*} \mathrm{x}^{2}$ & 0.953 \\
$g_{\mathrm{s}}, \mathrm{mmol} \mathrm{m}^{-2} \mathrm{~s}^{-1}$ & $\hat{\mathrm{y}}=1.712+0.289 \mathrm{x}-0.179^{\circ} \mathrm{x}^{2}$ & 0.422 \\
\hline
\end{tabular}

, * = significant at 10 and $5 \%$, respectively, by the $F$-test.

Increased photosynthesis rates in Si-treated plants were also observed in other studies (HATTORI et al., 2005; HASANUZZAMAN et al., 2010; SHEN et al., 2010; BYBRODI et al., 2012). With higher $\mathrm{Si}$ accumulation, drought-stressed sorghum plants absorbed more water and maintained high rates of stomatal conductance and photosynthesis, which in turn, increased the relative growth rate (dry matter production per unit of dry mass) and water use efficiency (HATTORI et al., 2005; SHEN et al., 2010).

The $\mathrm{Si}$ application decreased transpiration rate and increased stomatal conductance, as also observed in sorghum leaves under water stress conditions (HATTORI et al., 2005). Stomatal conductance grew to the intermediate $\mathrm{Si}$ rate and thereafter decreased, fitting a quadratic model. Gao et al. (2004) and Ma et al. (2004) stated that there is no evidence whether $\mathrm{Si}$ affects the stomatal response in crops that absorb less $\mathrm{Si}$, and whether it is a physical process, as in rice, or through other unknown processes. Agarie et al. (1998) and Ueno and Agarie (2005) mentioned that, by blocking the transpiration, Si physically influences the stomatal conductance by preventing water loss through stomata, modifying the physical properties of the guard cell walls. However, the mechanism varies according to the species. In sorghum, for example, Si deposited in leaves has no physical influence on stomata movement since no difference was observed in stomata response to light between Si-treated and untreated plants, under different light intensities and water stress conditions (HATTORI et al., 2007).

Furthermore, the cuticular transpiration rate (measured as transpiration rate in the dark) was not correlated with $\mathrm{Si}$ application, indicating that $\mathrm{Si}$ accumulation in sorghum leaves, in contrast to rice, has no physical influence on the maintenance of water status in the leaf blade (MATOH et al., 1986). According to Hattori et al. (2007), Si application decreases the transpiration rate. As a result, $\mathrm{CO}_{2}$ consumption is greater, consequently increasing 
stomatal conductance, as observed in this study (Table 2).

\section{CONCLUSIONS}

The sunflower 'Sunbright' accumulates Si in leaf trichomes.
The application of $\mathrm{Si}$ to the substrate for plant growth reduces the rates of transpiration, and increases net photosynthesis and stomatal conductance with applied rates.

The leaf thickness of sunflower is not affected by the addition of Si to the substrate.

RESUMO: A utilização de silício no cultivo de algumas plantas ornamentais em vasos e em casa de vegetação tem proporcionado aumento na produção e qualidade do produto final. No entanto, possíveis alterações fisiológicas e anatômicas causadas por este elemento precisam ser avaliadas. Objetivou-se com este estudo avaliar trocas gasosas e anatomia foliar de girassol ornamental cv. Sunbright em resposta à aplicação de doses de Si no substrato. O experimento foi conduzido em casa de vegetação e os tratamentos consistiram em cinco doses de $\mathrm{Si}$ : $0 ; 0,25 ; 0,50 ; 0,75$ e $1,00 \mathrm{~g} \mathrm{~kg}^{-1}$, em DBC, com quatro repetições. Para o estudo anatômico, amostras da região mediana do limbo do sexto par de folhas a partir do ápice foram coletadas e análises morfométricas realizadas. Tricomas da epiderme foram analisados usando-se as técnicas de diafanização e microscopia eletrônica de varredura acoplada a raios-X. Determinou-se a espessura da lâmina foliar, dos parênquimas paliçádico e lacunoso, do mesofilo e das faces abaxial e adaxial da epiderme. A taxa fotossintética líquida, condutância estomática e taxa de transpiração foram determinadas com o auxílio de um analisador de gás no infravermelho. Os dados foram submetidos à ANOVA e análise de regressão. O girassol ornamental cv. Sunbright acumula Si nos tricomas foliares. A espessura dos tecidos foliares do girassol não foi influenciada pela aplicação do Si ao substrato. Entretanto, houve redução da taxa de transpiração e aumento da taxa de fotossíntese líquida e da condutância estomática em resposta às doses de $\mathrm{Si}$.

PALAVRAS-CHAVE: Helianthus annuus L. Fotossíntese. Micromorfometria.

\section{REFERENCES}

AGARIE, S.; HANAOKA, N.; UENO, O.; MIYAZAKI, A.; KUBOTA, F.; AGATA W.; KAUFMAN, P. B. Effects of silicon on tolerance to water deficit and heat stress in rice plants (Oryza sativa L.), monitored by electrolyte leakage. Plant Production Science, v. 1, p. 96-103, 1998. https://doi.org/10.1626/pps.1.96

ASANUZZAMAN, M.; NAHAR, K.; FUJITA, M. Silicon and selenium: two vital trace elements that confer abiotic stress tolerance to plants. In: AHMAD, P.; RASOOL, S. (Ed). Emerging Technologies and Management of Crop Stress Tolerance, Volume 1: Biological Techniques. San Diego: Academic Press, 2014. P. 378-422.

ASHRAF, M.; RAHMATULLAH, R.; AHMAD, R. BHATTI, A. S.; AFZAL, M.; SARWAR, A.; BYBRODI, A. Effect of ascorbic acid and silicium on photosynthesis, antioxidant enzyme activity, and fatty acid contents in canola exposure to salt stress. Journal of Integrative Agriculture, v. 11, p. 1610-1620, 2012. https://doi.org/10.1016/S2095-3119(12)60164-6

CUNHA, K. P. V.; NASCIMENTO, C. W. A. Silicon effects on metal tolerance and structural changes in maize (Zea mays L.) grown on a cadmium and zinc enriched soil. Water Air Soil Pollut, v. 197, p. 323-330, 2008. https://doi.org/10.1007/s11270-008-9814-9

CURRIE, H. A., PERRY, C. C. Silica in plants: biological, biochemical and chemical studies. Annals of Botany, v. 100, p. 1383-1389, 2007. https://doi.org/10.1093/aob/mcm247

EPSTEIN, E. Silicon. Annual Review of Plant Physiology and Plant Molecular Biology, v. 50, p. 641-664, 1999. https://doi.org/10.1146/annurev.arplant.50.1.641

FOSTER, A. S. Practical Plant Anatomy. New York: Van Nostrand, 1949. 228 p. 
FRANTZ, J. M.; LOCKE, J. C.; DATNOFF, L.; OMER, M.; WIDRIG, A.; STURTZ, D.; HORST, L.; KRAUSE, C. R. Detection, distribution, and quantification of silicon in floricultural crops utilizing three distinct analytical methods. Communications in Soil Science and Plant Analysis, v. 39, p. 2734-2751, 2008. https://doi.org/10.1080/00103620802358912

GAO, X. P.; ZOU, C.; WANG, L.; ZHANG, F. Silicon improves water use efficiency in maize plants. Journal of Plant Nutrition, v. 27. p. 1457-1470, 2004. https://doi.org/10.1081/PLN-200025865

GONG, H.; ZHU, X.; CHEN, K.; WANG, S.; ZHANG, C. Silicon alleviates oxidative damage of wheat plants in pot sunder drought. Plant Science, v. 169, p. 313-321, 2005. https://doi.org/10.1016/j.plantsci.2005.02.023

GUNES, A.; PILBEAM, D. J.; INAL, A.; COBAN, S. Influence of silicon on sunflower cultivars under drought stress, I: Growth, antioxidant mechanisms, and lipid peroxidation. Communications in Soil Science and Plant Analysis, v. 39, p. 1885-1903, 2008. https://doi.org/10.1080/00103620802134651

GUNTZER, F.; KELLER, C.; MEUNIER, J-D. Benefits of plant silicon for crops: a review. Agronomy Sustainable Development, v. 32, p. 201-213, 2012. https://doi.org/10.1007/s13593-011-0039-8

HAJIBOLAND, R.; ALI ASGHARPOUR, M.; DASHTBANI, F.MOVAFEGHI, A.; DADPOUR, M. R. Localization and study of histochemical effects of excess $\mathrm{Mn}$ in sunflower (Helianthus annuus L. cv. Azarghol) plants. Journal of Science Islamic Republic of Iran, v. 19, p. 305-315, 2008.

HATTORI, T.; INANAGA, S.; ARAKI, H.; AN, P.; MORITA, S.; LUXOVÁ, M.; LUX, A. Application of silicon enhanced drought tolerance in Sorghum bicolor. Physiologia Plantarum, v. 123, p. 459-466, 2005. https://doi.org/10.1111/j.1399-3054.2005.00481.x

HATTORI, T.; SONOBE, K.; INANAGA, S.; AN, P. TSUJI, W.; ARAKI, H.; ENEJI, A. E.; MORITA, S. Short term stomatal responses to light intensity changes and osmotic stress in sorghum seedlings raised with and without silicon. Environment and Experimental Botany, v. 60, p. 177-182, 2007.

https://doi.org/10.1016/j.envexpbot.2006.10.004

HOSSAIN, M.T.; MORI, S.; SOGA, K.; WAKABAYASHI, K.; KAMISAKA, S.; FUJII, S.; YAMAMOTO, R.; HOSON, T. Growth promotion and an increase in cell wall extensibility by silicon in rice and some other Poaceae seedlings. Journal of Plant Research, v. 115, p. 23-27, 2002. https://doi.org/10.1007/s102650200004

IMTIAZ, M.; RIZWAN, M. S.; MUSHTAQ, M. A.; ASHRAF, M.; SHAHZAD, S. M.; YOUSAF, B.; SAEED, D. A.; RIZWAN, M.; NAWAZ, M. A.; MEHMOOD, S.; TU, S. Silicon occurrence, uptake, transport and mechanisms of heavy metals, minerals and salinity enhanced tolerance in plants with future prospects: A review. Journal of Environmental Management, v. 30, p. 1-9. https://doi.org/10.1016/j.jenvman.2016.09.009

JOHANSEN, D. A. Plant microtechnique. New York: McGraw Hill Book, 1940. 523 p.

KERBAUY, G. B. Plant Physiology. Rio de Janeiro: Guanabara Koogan, 2004. 452 p.

LANNING, F. C.; ELEUTERIUS, L. N. Silica depositions in some C3 and C4 species of grasses, sedges and composites in the USA. Annals of Botany, v. 64, p. 395-410, 1989.

https://doi.org/10.1093/oxfordjournals.aob.a087858

LAVISNKY, A. O.; DETMANN, K. C.; REIS, J. V.; ÁVILA, R. T.; SANGLARD, M. L.; PEREIRA, L. F.; SANGLARD, L. M. V. P.; RODRIGUES, F. A.; DAMATTA, F. M. Silicon improves rice grain yield and photosynthesis specifically when supplied during the reproductive growth stage. Journal of Plant Physiology, v. 206, p. 125-132, 2016. https://doi.org/10.1016/j.jplph.2016.09.010

MA, J. F. Role of silicon in enhancing the resistance of plants to biotic and abiotic stresses. Soil Science and Plant Nutrition, v. 50, p. 11-18, 2004. https://doi.org/10.1007/s00018-008-7580-x 
MA, J. F.; MIYAKE, Y.; TAKAHASHI, E. Silicon as a beneficial element for crop plants. In: DATNOFF, L.E.; SNYDER, G.H.; KORNDORFER, G.H. Silicon in agriculture. Amsterdam, Elsevier Science, 2001.p. 17-39. https://doi.org/10.1080/00380768.2004.10408447

MA, J. F.; YAMAJI, N. A cooperated system of silicon transport in plants. Cell Press, v. 7, p. 435-442, 2015.

MA, J. F.; YAMAJI, N. Functions and transport of silicon in plants. Cellular and Molecular Life Science, v. 65, p. 3049-3057, 2008.

MAQSOOD, M. A.; KANWAL, S. Amelioration of salt stress in sugarcane (Saccharum officinarum L.) by supplying potassium and silicon in hydroponics. Pedosphere, v. 20, p. 153-162, 2010.

https://doi.org/10.1016/S1002-0160(10)60003-3

MATOH, T.; KAIRUSMEE, P.; TAKAHASHI, E. Salt-induced damage to rice plants and alleviation effect of silicate. Soil Science and Plant Nutrition, v. 32, p. 295-304, 1986.

https://doi.org/10.1080/00380768.1986.10557506

METCALFE, C.R.; CHALK, L. Anatomy of the dicotyledons: leaves, stem, and wood in relation to taxonomy with notes on economic uses. Oxford: Clarendon Press, 1957. 1500 p.

O'BRIEN, T. P.; FEDER, N.; MCCULLY, M. E. Polychromatic staining of plant cell walls by toluidine blue. Protoplasma, v. 59, p. 367-373, 1964. https://doi.org/10.1007/BF01248568

SAVANT, N.K.; KORNDÖRFER, G. H.; DATNOFF, L. E.; ANYDER, G. H. Silicon nutrition and sugarcane production: a review. Journal of Plant Nutrition, v. 22, p. 1853-1903, 1999.

https://doi.org/10.1080/01904169909365761

SHEN, X; ZHOU, Y.; DUAN, L.; ENEJI, A. E.; LI, J. Silicon effects on photosynthesis and antioxidant parameters of soybean seedlings under drought and ultraviolet-B radiation. Journal of Plant Physiology, v. 167, p. 1248-1252, 2010. https://doi.org/10.1016/j.jplph.2010.04.011

SIVANESAN, I.; PARK, S. W. The role of silicon in plant tissue culture. Frontiers in Plant Science, v. 5, p. $1-4,2015$.

SOARES, J. D. R.; PASQUAL, M.; ARAUJO, A. G.; CASTRO, E. M.; PEREIRA, F. J.; BRAGA, F. T. Leaf anatomy of orchids micropropagated with different silicon concentrations. Acta Scientiarum Agronomy, v. 34, p. 413-421, 2012. https://doi.org/10.4025/actasciagron.v34i4.15062

TRIPATHI, D.K.; SINGH, V. P.; GANGWAR, S.; PRASAD, S. M.; MAURYA, J. N.; CHAUHAN, D. K. Role of silicon in enrichment of plant nutrients and protection from biotic and abiotic stresses. In: AHMAD, P.; WANI, M. R.; AZOOZ, M. M.; TRAN, L. S. P. Improvement of crops in the era of climatic changes. New York: Springer, 2014. p. 39-56. https://doi.org/10.1007/978-1-4614-8830-9_2

UENO, O.; AGARIE, S. Silica deposition in cell walls of the stomatal apparatus of rice leaves. Plant Production Science, v. 8, p. 71-73, 2005. https://doi.org/10.1626/pps.8.71

YIN, L.; WANG, S.; LIU, P.; WANG, W.; CAO, D.; DENG, X.; ZHANG, S. Silicon-mediated changes in polyamine and 1-aminocyclopropane-1- carboxylic acid are involved in silicon-induced drought resistance in Sorghum bicolor L. Plant Physiology and Chemistry, v. 80, p. 268-277, 2014.

https://doi.org/10.1016/j.plaphy.2014.04.014

ZANÃO JÚNIOR, L. A.; ALVAREZ V, V. H.; CARVALHO-ZANÃO, M. P.; FONTES, R. L. F.; GROSSI, J. A. S. Produção de rosas influenciada pela aplicação de doses de silício no substrato. Revista Brasileira de Ciência do Solo, v. 37, p. 1611-1619, 2013. https://doi.org/10.1590/S0100-06832013000600017. 